UDC 621.3.014:621.365.2

Yu. H. Kachan, Dr. Sc. (Tech), Prof., orcid.org/0000-0001-9984-3646,

V. Yu. Mishchenko, orcid.org/0000-0003-0673-2504
DOI: $10.29202 /$ nvngu/2019-3/16

Zaporozhye National Technical University, Ukraine, Zaporizhzhia, e-mail: m.vlad.u@i.ua

\title{
DETERMINATION OF DISTRIBUTION OF INTRODUCED ENERGY BY VOLUME OF ORE-THERMAL FURNACE
}

Purpose. Creation of a mathematical model of the process of energy input into an ore-thermal furnace and its distribution in volume taking into account both the electrical and occurring thermal phenomena and the representation of the bath as a set of elementary components. The latter ones, due to electrical resistance, consume electricity which is converted into heat, and then it is redistributed in volume through heat transferring. This will enable to obtain 3D changing picture in the temperature field of the working space and to solve various issues and practical problems related to energy efficiency improvement in the process of obtaining ferroalloys and in the short power supply of the furnace.

Methodology. The mathematical model creation is based on a real sequence of processes occurring in the furnace working space and the continuous interconnection between thermal and electrical transformations. This approach makes it possible to implement the description of the process in the form of an algorithm, whose calculated blocks are constructed on the basis of the following methods: the theory of electric circuits; the description of the volume space based on cylindrical coordinates; the analysis of the processes of heat removing in materials with different aggregate state due to heat transferring.

Findings. A 3D picture of the temperature field in the furnace bath in the process is created, which in real time allows determining the temperature state of elemental volumes and the moments of melt appearance in them as well separating furnace zones, which require additional energy input to calculate the volume and dynamics of the finished melt formation and the time of its discharging. Due to the information obtained about the physical condition of the charge at any place of the furnace working space, it was possible to track the changing dynamics of the material surface relief and to determine the place of the charge filling in dynamics.

Originality. A possibility of energy distribution in the bath of ore-thermal furnace in dynamics and calculation of the temperature field in it was determined. A mathematical model of the smelting ferroalloys process where the relationship of electrical and thermal processes in the volume of the charge can be considered was proposed. All these allow determining the indicators which affect the power efficiency melting.

Practical value. The use of the suggested model allows calculating the amount of energy input at any elemental volume of the ore-furnace bath over a certain period of time, and solving the practical problems of power efficiency process.

Keywords: ore-thermal furnace, electric energy, specific electrical resistance

Introduction. Ferroalloy production is one of those branches of industry, the future of which is associated with the capabilities of the country's energy base. The energy intensity of Ukrainian metal products is almost 1.5 times higher than that of the world's best producers [1]. Steel production in Ukraine amounted to 33.2 million tons last year, which is only $1 \%$ higher than the corresponding figure of the previous year. This proved to be enough to save Ukraine the tenth place in the ranking of world producers of metallurgical products [2]. The increase in energy prices has sharply raised the question of new energy-saving metallurgical technologies introduction. The production of various types of steel is closely related to the nomenclature of ferroalloys. Ukrainian metallurgical plants are the main enterprises of the industry, which according to their resource base, technological processes, activity performances are very heterogeneous [3]. Manganese ferroalloys, including ferro-silicomanganese, for the tonnage of smelting and specific consumption in the manufacture of steel in converters and electrical furnaces occupy a leading place.

(c) Kachan Yu. H., Mishchenko V.Yu., 2019
The production of crude steel in the world is constantly growing and currently stands at about 1.6 billion tons in a year. In connection with this, the need for the steelmaking industry in manganese and other ferroalloys is systematically increasing [4].

Ferroalloys are smelted in ore-thermal furnaces (OTF) of various designs and capacities, electrical and geometric parameters of which are determined by the nature of processes occurring in them. In aggregates of low power it is little noticeable. The similarity of electrical modes allows using one and the same bath in different cases. With the growth of furnace capacity and the complication of their designs, as well as increased requirements for product quality, it became necessary to choose a technological unit which would take into account all the technological features of the production being considered.

The technological processes occurring in the orethermal furnace bath are energy-intensive and very diverse. Some of them proceed continuously, while others function cyclically and require full melting of loaded materials. The most important parameter of the furnace is the electrical resistance of the bath, which depends on 
a significant number of factors: the resistivity of the charge materials in it, the geometric dimensions, as well as the number and parameters of the electrodes.

Almost all OTFs are the objects of direct heating. Heat energy is released directly in their baths as a result of the active charge resistance to an electric current supplied by means of coal or graphite electrodes. The latter ones, of course, have some additional power, but it is insignificant compared to electric and in fact does not play a significant role in the energy balance of the smelting.

Literature review. Modern electric arc and ore-thermal furnaces are complex installations with variety of electromechanical equipment. They consist of a power supply (furnace transformer), a kiln (baths with electrodes) and a short electrical network connecting them together. Traditionally, the furnace working space is divided into three main zones, which are characterized by the nature of energy processes in them [5]. This is an area of materials with relatively low electrical conductivity, an arc zone, and a zone where solid and liquid materials with high electrical conductivity are located. The energy distribution between these zones characterizes the specificity of a concrete process and a concrete furnace.

Unlike arc furnaces, electric energy transformation into heat in the ore-thermal furnaces occurs not only in the arc, but also directly in those materials which are melted. In the last decade, systems in the automated control of technological processes are increasingly using methods based on the direct analysis of phenomena which are accompanied by the passage of electric current through the conductive medium. This medium includes the charge for ferroalloys smelting. An important property of such materials is their specific electrical resistance. Its value, in other equal conditions, is determined both by the amount and by the granulometric composition of the charge material components and it increases with their temperature increasing.

Many scientists conducted mathematical modeling of electric fields of three-phase ore-thermal furnaces, and also developed a method for conducting theoretical studies with the help of conformal reflections to determine physical fields in ore-thermal melting furnace [6]. Qualitatively, the electric field of furnace is sufficiently illuminated, but available information is not enough to calculate the power, electrical transformations and temperatures at each point of the bath volume accurately.

In the famous scientific works by Armenskyi S. V., Markov A.V., Savkyn A.V. the distribution of electric energy in analyzed objects is considered in sub-electrode space only; however, from studies by Hasyk M.I. and Liakyshev N. P. it is clear that more than half of the heat is released directly in the charge due to its electrical resistance, and the amount of energy input, thus, at any part of the furnace bath is significant and can be determined by the current magnitude and the results of the heat analysis of the ionic processes taking place there.

Also, there is a need for further study of the interactions between the parameters of power supply systems and physico-chemical processes occurring in the fur- nace under various external influences, in order to increase the efficiency of energy and heat and mass exchange processes [7].

Purpose. As it was noted in [8], one of the main steps in developing complex model that would allow determining the energy distributions in the ore-thermal furnace is to break down its working space into elemental volumes and to determine the amount of energy input into them at the expense of electric current. This allows obtaining a temperature field over the furnace volume and solving a large number of tasks related to the technological regimes and their energy efficiency.

Results. To determine the amount of electrical energy input in each elemental volume of the furnace, it is necessary to determine how exactly the current in the bath working space flows. The charge for smelting ferroalloys is the medium where currents flow along definite lines between the electrodes. It is reasonable to assume that they will have an arc shape and will be directed to the edges of the bath and to its center. They pass or will pass between the ends of the electrodes towards the bath bottom, respectively, in the horizontal and vertical flats. This assumption is based on the scientific works by Strunskyi B. M. and Dantsys Ya. B., where lines (trajectories) of currents flow in the sub-electrode space are depicted as lines directed from the electrode to the OTF bath bottom and have an arc character.

To lay the arcs between the electrodes, it is necessary to know their radius and coordinates. They are on a line passing through the third electrode and are perpendicular to the shortest path between the two others. The radius and the length of each arc may be calculated using formulas corresponding to well-known geometric dependencies for finding different parameters of the circle.

The chain of the proposed bath breaking of the orethermal furnace into elemental volumes is shown in Fig. 1. Thanks to the given algorithm it is possible to synthesize a simplified segment model of the furnace volume in three-dimensional space, which in future may be used as the basis for many calculations according to the working indications of the considered technological unit.

In Fig. 2, for example, the paths for such current flow between the electrodes with the phases $A$ and $B$ are shown.

To simulate the process of energy distribution in the bath of ore-thermal furnace, it is also necessary to break its internal volume into elementary components. There are many ways to do it, but we choose and somewhat change the method based on the system of cylindrical coordinates which has been used successfully before, to construct a dynamic temperature field model in an electric heat accumulating converter.

The geometric form of the ore-thermal furnace bath, where the melting process takes place, can be shown as a cylinder with height $H$ and radius $R$. We split it into series of elementary volumes in the form of a sector with sides $\Delta R, \Delta z$ and an angle $\Delta \phi$, as represented in Fig. 3 . We place further calculation points in the geometric centers of each separated elementary volumes.

We use the following sings: $R_{l}$ is the radius of the bath; $\Delta V$ is the volume of the elemental sector; $k$ is the 


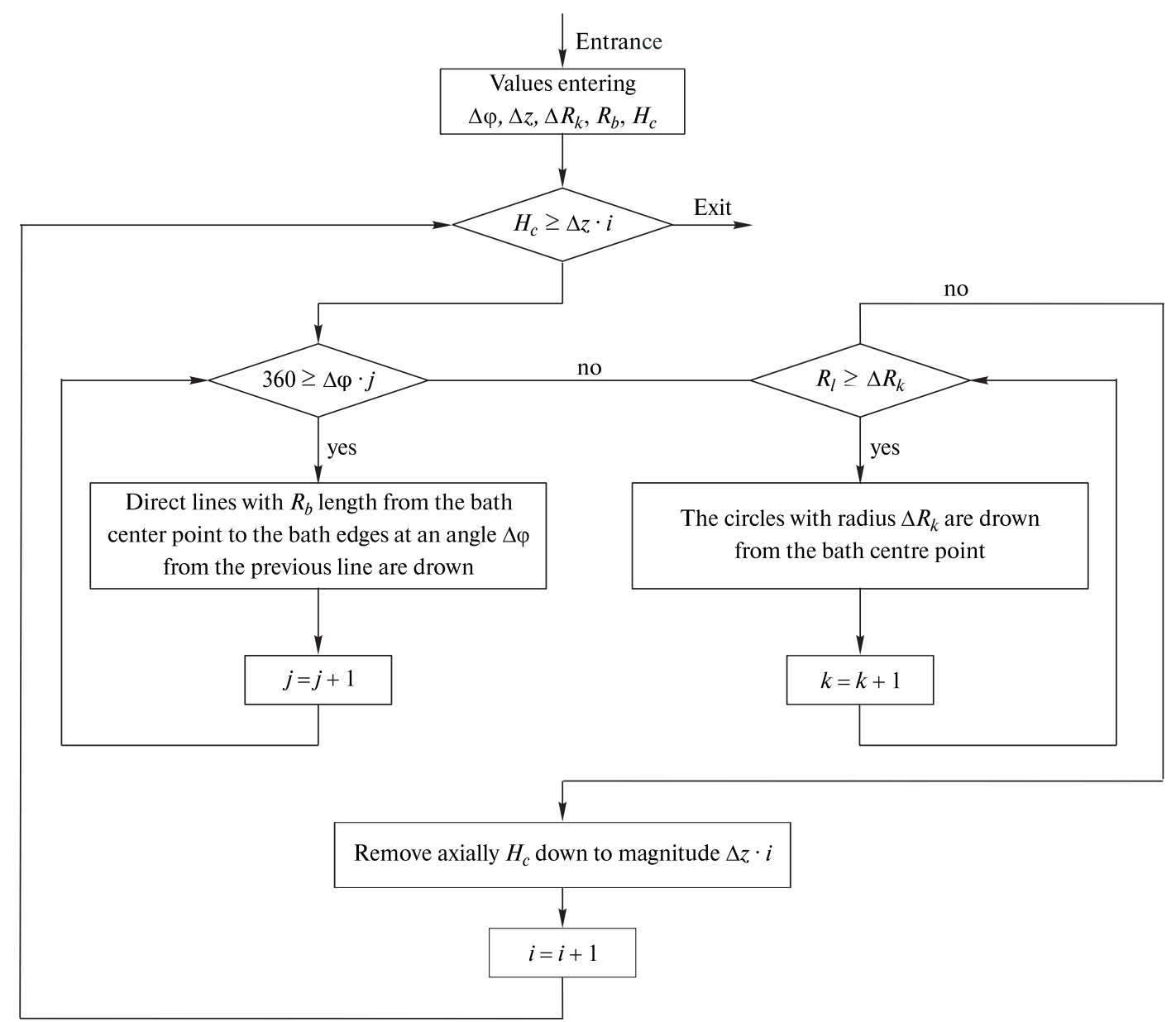

Fig. 1. The algorithm of breaking into elemental volumes the ore-thermal furnace bath inner area

number of elemental volume behind the axis $R ; N_{\varphi}$ is the number of segments $\Delta \varphi$ of the cylinder's volume breaking behind angle $\varphi ; N_{z}$ is the number of intervals $\Delta z$ of the cylinder's volume breaking behind the height $H_{c}$ of bath filling with the charge; $R, \varphi, z$ are the coordinates of the center; $\Delta \tau$ is the time interval.

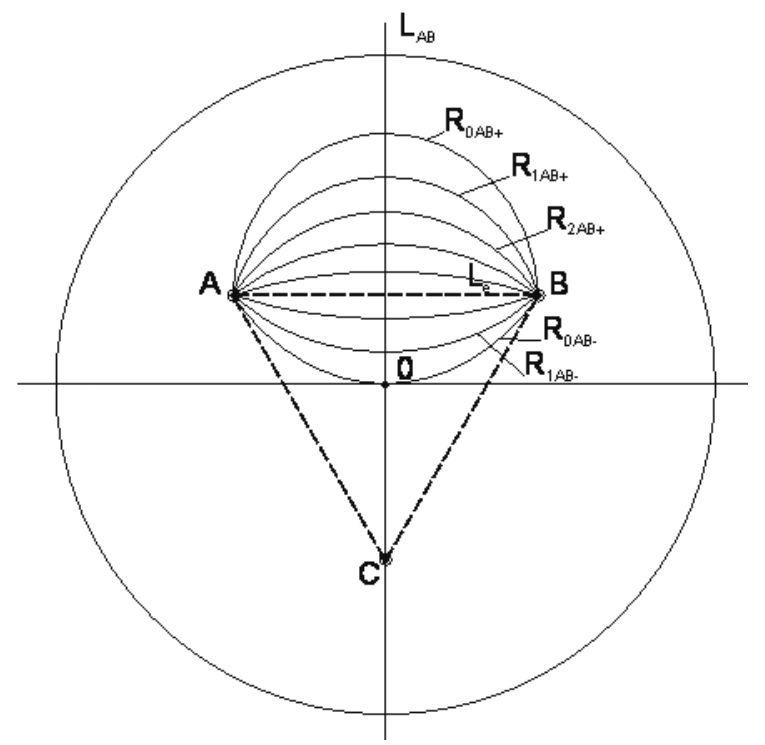

Fig. 2. The paths of current flow between the electrodes of phases $A$ and $B$
The meaning of the parameters $\Delta z$ and $\Delta \varphi$ can be calculated according to the formula

$$
\Delta \varphi=\frac{360}{N_{\varphi}} ;
$$

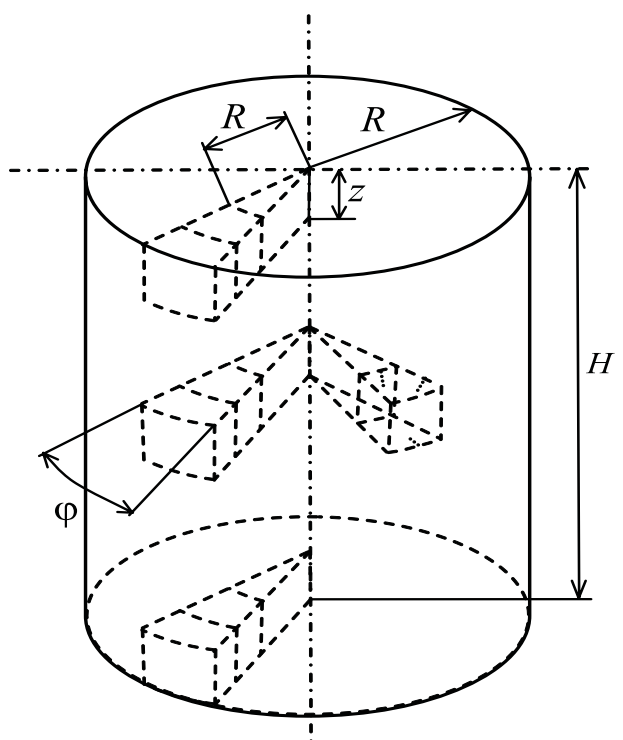

Fig. 3. The partitioning of ore-thermal furnace bath into elemental volumes 


$$
\Delta z=\frac{H_{c}}{N_{z}},
$$

where $N_{\varphi}$ is the number of segments of the cylinder breaking behind angle $\varphi ; N_{z}$ is the number of intervals for cylinder breaking in height; $H_{c}$ is the height of bath filling with charge.

Having assumed the constant value $\Delta V$ for each elementary volume, we define the intervals $\Delta R_{k}$ along the $R$ axis

$$
\Delta R_{k}=\sqrt{\frac{\Delta V \cdot N_{\varphi}}{\pi \cdot \Delta z}} \cdot(\sqrt{k+1}-\sqrt{k}),
$$

where $\Delta V$ is the volume of an elementary particle; $k$ is the circle number along the axis $R ; N_{\varphi}$ is the number of segments of the cylinder breaking behind the angle $\varphi ; \Delta z$ is the size of the elemental volume at the height of filling the bath with the charge.

The initial information for the algorithm is the values: $\Delta \varphi, \Delta z, \Delta R_{k}, R_{l}, H_{c}$, which are calculated according to the formulas given above or which may be geometric parameters of the furnace itself. The $j, k, i$ variables act as a counter-cycle to get over the next step. After completion of all cycles, there is an exit from the algorithm for further calculations of electrical parameters and quantities on the base of such OTF bath breaking.

So, if the elementary volumes are very small in size, then through a large array of data, the speed of the necessary calculations decreases. The division of the furnace working space into a small number of specified segments can lead to inadequate model. Therefore, at each particular case, this issue needs to be solved separately.

After determination of current paths spreading, using the proposed version of the OTF working space breaking into elemental volumes, we obtain two-dimensional images in the horizontal flat (Fig. 4) and in the sub-electrode space (Fig. 5).

The charge in each single volume of elemental component $\Delta V$ at a certain temperature has its specific electrical resistance [9]. The average electrical resistance can be calculated as

$$
R_{R, \varphi, z}=\rho_{R, \varphi, z}(t) \cdot \Delta V,
$$

where $R_{R, \varphi, z}$ is the average value of the electrical resistance of the element; $\Delta V$ is the volume of the elementary part; $\rho_{R, \varphi, z}(t)$ is the specific resistance of elementary volume.

Using ways of current spreading in the OTF working space and breaking the bath into elementary volumes on the basis of the proposed method, it is possible to calculate the amount of electrical energy introduced into them for a certain period of time. To do this, it is necessary to allocate a specific trajectory of current flow and calculate its full electrical resistance. The latter can be defined as the total resistance of all charge sections through which the described current passes

$$
R_{t}=\sum R_{R, \varphi, z},
$$

where $R_{t}$ is full electrical resistance of any trajectory of current flow; $R_{R, \varphi, z}$ is the average value of the electrical resistance of the element.

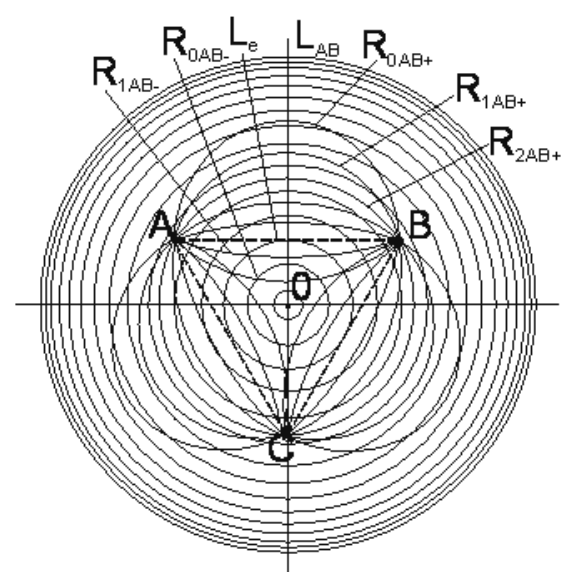

Fig. 4. The ways of current spreading between three electrodes in the bath working space, the volume of which is pre-divided into elementary components

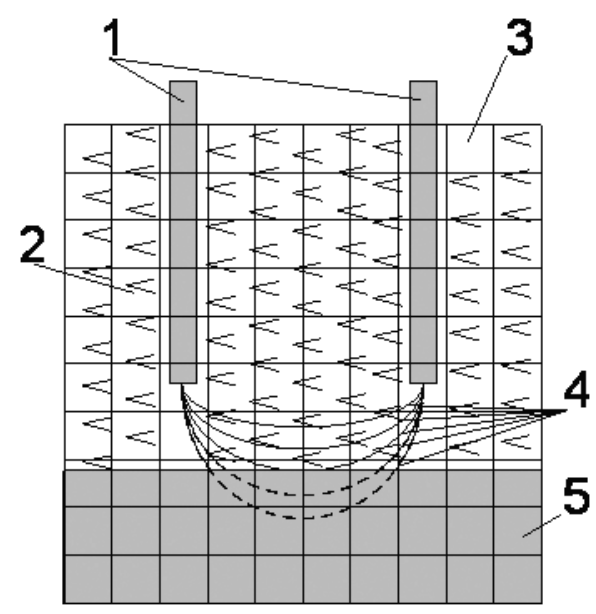

Fig. 5. Ways of current spreading between the electrodes of phases $A$ and $B$ in the sub-electrode space:

1 - electrodes; 2 - charge in solid state; 3 - elementary volume; 4 - current flow paths; 5 - liquid melt

It is clear that in the given system of coordinate, it is necessary to select only those elementary volumes where the current passes and the resulting resistance is summed up; and this resulting resistance is calculated for a specific temperature of the charge. As a result, the value of the current spreading over the observed lines can be obtained

$$
I_{i}=\frac{U}{R_{t}},
$$

where $I_{i}$ is the current strength on the $i^{t h}$ way; $U$ is the voltage between the corresponding phases; $R_{t}$ is full electrical resistance on the $i^{\text {th }}$ path.

Consequently, having substituted expressions $(1,2)$ in (3), we obtain the dependence for defining the current strength along certain spreading trajectory

$$
I_{i}=\frac{U}{\sum \rho_{R, \varphi, z}(t) \cdot \Delta V},
$$

where $I_{i}$ is the current strength on the $i^{\text {th }}$ way; $U$ is the voltage between the corresponding phases; $\rho_{R, \varphi, z}(t)$ is the 
specific resistance of elementary volume; $\Delta V$ is the volume of an elementary particle.

As a result, the amount of energy emitted in the elementary volume due to electric current over a time interval $\Delta \tau$ can be defined as

$$
Q_{e(R, \varphi, z)}=I_{i}^{2} \cdot R_{R, \varphi, z} \cdot \Delta \tau
$$

where $I_{i}$ is the current strength on the $i^{\text {th }}$ way; $R_{R, \varphi, z}$ is the average value of the electrical resistance of the element; $\Delta \tau$ is the time interval.

If, through one and the same elementary volume several different trajectories of current spreading pass, then the resulting value of the latter is determined as the sum of components for each of them. Then (4) will take the form

$$
Q_{e(R, \varphi, z)}=\left(\sum I_{i}\right)^{2} \cdot R_{R, \varphi, z} \cdot \Delta \tau
$$

where $\sum I_{i}$ is the sum of currents for the $i^{\text {th }}$ ways of spreading, passing through the elementary volume which is considered.

Thus, knowing the amount of energy emitted in each elementary volume due to the passage of the electric current through it, it is possible to obtain, with the help of the appropriate algorithm, the temperature field of the ore-thermal furnace bath in dynamics [10], the sequence of such calculation is presented in Fig. 6. Input data in this case are those initial values of the following charge parameters: specific density and electrical resistance, coefficient of thermal conductivity, mass heat capacity, all of them are determined by the composition of the charge and its temperature.

The definition of the introduced amount of heat at the expense of electric current into each elementary vol- ume is carried out for a certain time interval $\Delta \tau$. Knowing the lines of current spreading and its data in spreading directions of the melting bath, and taking into account the elementary volumes on which the furnace is divided, one can determine the energy that was allocated in each of them by the (6), given above.

The next step is to calculate the value of the temperature of each elementary volume, which can be defined by the formula for changing the heat capacity

$$
\Delta J_{R, \varphi, z}=c_{m(R, \varphi, z)} \rho_{(R, \varphi, z)}\left(t_{R, \varphi, z}^{\tau+\Delta \tau}-t_{R, \varphi, z}^{\Delta \tau}\right) \Delta V,
$$

where $c_{m}$ is the mass heat capacity of elementary volume; $\rho$ is the specific density of the calculated volume; $t^{\tau}, t^{\tau+\Delta \tau}$ is the estimated temperature at the time $\tau$ and $\tau+\Delta \tau$ in the center of the elementary volume $(R, \varphi, z)$.

Taking into account the fact that $\Delta J_{R, \varphi, z}=Q_{e(R, \varphi, z)}$, and since the change in heat capacity was due to the transformation of electric energy into heat, (5) for calculating the value of the temperature of the elemental volume at the time $\tau+\Delta \tau$, it will takes the form

$$
t_{R, \varphi, z}^{\tau+\Delta \tau}=\frac{Q_{e(R, \varphi, z)}}{c_{m(R, \varphi, z)} \rho_{R, \varphi, z} \Delta V_{R, \varphi, z}}+t_{R, \varphi, z}^{\Delta \tau},
$$

where $t_{R, \varphi, z}^{\tau+\Delta \tau}$ is the value of the temperature elementary volume at the time $\tau+\Delta \tau ; t_{R, \varphi, z}^{\Delta \tau}$ is the value of the temperature elementary volume at previous time $\tau ; Q_{e(R, \varphi, z)}$ is the energy emitted in the elementary volume due to electric current in the time interval $\Delta \tau$.

At the same time, at a certain temperature the process of coke combustion begins, which is accompanied

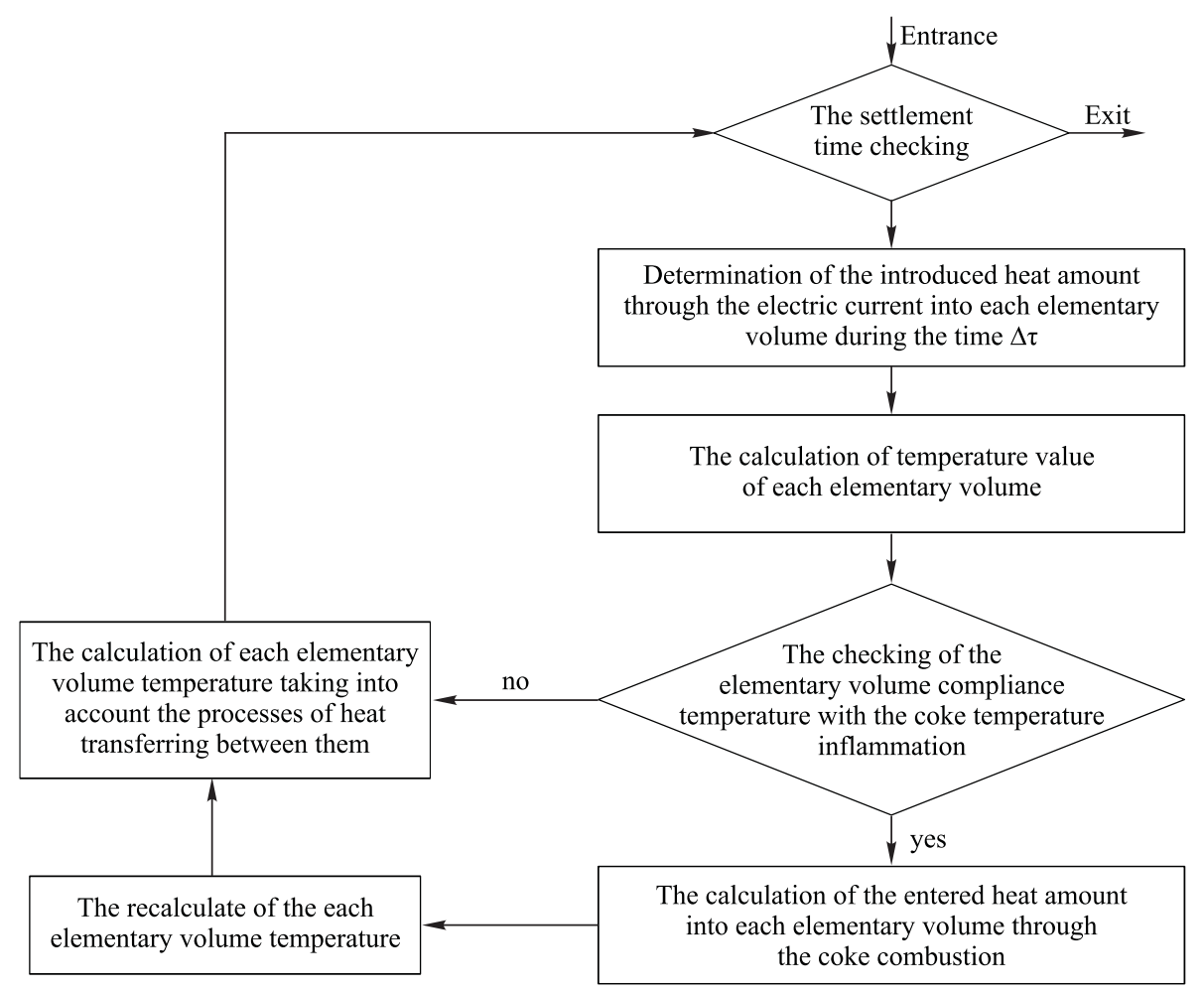

Fig. 6. Block diagram of the algorithm for calculating the temperature field of the bath of ore-thermal furnace in dynamics 
by an additional heat release. This is taken into account by correcting the formula

$$
t_{R, \varphi, z}^{\tau+\Delta \tau}=\frac{Q_{\grave{a}(R, \varphi, z)}+m_{(R, \varphi, z)} \cdot q}{c_{m(R, \varphi, z)} \rho_{R, \varphi, z} \Delta V_{R, \varphi, z}}+t_{R, \varphi, z}^{\Delta \tau},
$$

where $m_{(R, \varphi, z)}$ is the mass of the deoxidase, which in an elementary volume; $q$ is the specific heat of coke combustion.

Here, the fact is taken into account that the energy in the elementary volume is introduced at the expense of the current flow through the charge and the chemical reaction of the breeze coke combustion during the smelting of ferroalloys. Of course, the allocation of heat of the latter is one-time phenomenon, so the calculation (6) is used only when the value of the temperature of coke inflammation is reached.

Due to the processes of heat transferring, heat which is released in any elemental volume, disperses in the OTF bath and therefore it changes the effective value of temperature.

Therefore, the algorithm for calculating the temperature field of the ore-thermal furnace bath over time interval $\Delta \tau$ consists of two cycles. Knowing the value of elementary volume temperature after electric energy was introduced into it (Block 1 and Block 2), one can carry out the inspection of achieving the temperature of inflammation of coke. If it takes place, an additional input of heat due to its combustion process must be taken into account (Blocks 4, 5). After it the heat dispersion process is simulated due to the heat transferring (Block 6) and the current value of temperature is recalculated.

This is done by using the thermal balance equation for particular elementary volume that corresponds to the formula

$$
\Delta J_{R, \varphi, z}=\sum_{I}^{V I} Q_{i},
$$

where $Q_{\mathrm{I}}, Q_{\mathrm{II}}, Q_{\mathrm{III}}, Q_{\mathrm{IV}}, Q_{\mathrm{V}}, Q_{\mathrm{VI}}$ stand for the amount of heat that comes in or comes out of the elemental volume in time $\Delta \tau$ through the corresponding index surfaces; $\Delta J_{R, \varphi, z}$ is the thermal capacity changing of the latter. Indices $i$ is the surface number of the elementary volume.

According to the Fourier hypothesis, the amount of heat passing through the elementary volume that is inside the cylinder, on the side of the $i^{\text {th }}$ surface, may be represented as

$$
Q_{i}=-\lambda_{i} \operatorname{gradt}_{i} S_{i} \Delta \tau Q_{i}=-\lambda_{i} \operatorname{gradt}_{i} S_{i} \Delta \tau,
$$

where $\lambda_{i}$ is the equivalent thermal conductivity in the $i^{\text {th }}$ direction; gradt $t_{i}$ is the temperature gradient in the $i^{\text {th }}$ direction; $S_{i}$ is the area of the $i^{\text {th }}$ surface.

The initial information of the synthesized complex model considered in this work is the values of elemental volume temperatures calculated after the electrical, chemical and thermal processes which occurred within them through the time interval $\Delta \tau$. After this process finishes, everything starts from the beginning and the temperature values for the next step are calculated. Thus, calculating the temperature values at all given points of the ore-thermal furnace bath, in accordance with the given algorithm, we obtain the temperature distribution by volume at all intervals of the technological process and get dynamic image of the furnace temperature field changing during the ferroalloys smelting.

As a result, with the help of the given chain calculations, the dynamics of the energy input distribution by the volume of the OTF bath is determined. This allows solving a number of technological tasks in order to increase the energy efficiency of the processes being observed.

The presented algorithm characterizes the electrical and thermal engineering processes occurring in the orethermal furnace bath entirely. In this case, in contrast to other similar calculations for the simulation of temperature distribution [11], simple calculation formulas are used, and the charge electric resistance, which changes with temperature increasing at each interval of time, is adjusted.

Conclusions. According to the algorithm proposed above, the ore-thermal furnace bath is represented as a set of elementary identical volumes. This allows making the necessary calculations for the consumed energy in each of them.

It is suggested to assume that current trajectories passing through the charge have the form of arcs which are located between the electrodes centers and move in direction towards the edges of the bath and to its center. By simulating the paths of current spreading, it is possible to calculate the amount of input energy into separate bath volume and into entire furnace working space for a certain period of time. Repeating these calculations for the following intervals of time $\Delta \tau$ we obtain the dynamics of electric and thermal energy distribution in the volume of the ore-thermal furnace bath.

The presented algorithm for calculation of the orethermal furnace bath temperature field during ferroalloys smelting takes into account the important aspects of this complex technological process. Namely:

- the heat introduction into the bath volume through electric energy, because of the electrical resistance of the charge materials;

- the allocation of additional heat of breeze coke burning;

- the heat redistribution in the ore-thermal furnace bath volume because of heat transferring.

With this algorithm it is possible to obtain a 3D picture of the furnace bath temperature field at any time, that is, to trace its dynamics.

\section{References.}

1. Fedina, I. V. (2014). Energy saving in the production of ferrous and non-ferrous metals. Information technology in education, science and production, 4(9), 152-159. 2. Hryshchenko, S. H., Hasyk, M. I., Kutsyn, V. S., Soloshenko, P.A., \& Kudriavtsev, S. L. (2014). State, problems and prospects of development of the ferroalloy industry in Ukraine. Metallurgy, 2(2), 14-17.

3. Kutsyn, V.S. (2013). Newest energy-saving technologies of manganese ferroalloys production in electric furnaces. New materials and technologies in metallurgy and machine-building, 3, 168-183. 
4. Kolesnyk, V. M. (2014). Assessment of the production of ferroalloy products as an important component of the metallurgical complex of Ukraine. Economic space: $\mathrm{Col}$ lection of scientific works, 89, 19-28.

5. Nekhamin, S. M. (2013). Management of the energy structure of the working space of arc steelmaking and ore-thermal furnaces - the mechanism of increasing the efficiency of their work. Electrometallurgy, 11, 9-16. 6. Levchenko, S. A. (2016). Electromagnetic and thermal fields of ore-thermal melting furnace. Herald NTU "KhPI". Series: Mechanic-technological systems and complexes, 17(1189), 76-80.

7. Artiukh, F. S., \& Kukharev, A. L. (2014). Ways to improve the energy efficiency of powerful electric furnaces. Herald NTU "KhPI". Series: Energy: Reliability and Energy Efficiency, 56(1098), 11-21.

8. Kachan, Yu. G., \& Mishchenko, V. Yu. (2018). About the integrated approach at modeling of work of orethermal furnace. Metallurgy: scientific works of Zaporizhzhia State Engineering Academy, 1(39), 94-96.

9. Bakyrov, A. H., Zhunusov, A. K., Chekymbaiev, A. F., \& Shoshai, Zh. (2018). Investigation of the electrical resistivity of charge mixtures for smelting ferrosilicoaluminium. Science and technology of Kazakhstan, 2, 14-18. 10. Kachan, Yu. H., Liush, Yu. B., \& Mishchenko, V. Yu. (2018). Algorithm for calculating the temperature field of a bath of an ore-thermal furnace. Herald of Khmelnytskyi National University, 3(261), 19-22.

11. Lobov, V.Y., \& Kotliar, M. O. (2015). Simulation of temperature distribution in a layer of gas-air evaporators of an air-chamber in conveyor furnaces of the plant of connection. Scientific bulletin NGU, 2, 109-117.

\section{Визначення розподілу введеної енергії за об'ємом руднотермічної печі}

\section{Ю. Г. Качан, В. Ю. Міменко}

Запорізький національний технічний університет, м. Запоріжжя, Україна, e-mail: m.vlad.u@i.u

Мета. Створення математичної моделі процесу введення енергії до руднотермічної печі та її розподілу за об’ємом з урахуванням як електричних, так і теплових явищ, що відбуваються в ній і представлення ванни у вигляді сукупності елементарних складових. Останніми, за рахунок електричного опору, споживається електроенергія, що перетворюється в теплову, а потім перерозподіляється в об'ємі шляхом теплопередачі. Це в подальшому дасть можливість отримати 3D картину зміни температурного поля робочого простору й вирішувати практичні задачі щодо підвищення енергоефективності як самого процесу одержання феросплавів, так і короткої електричного мережі живлення печі.

Методика. Створення математичної моделі базується на реальній послідовності процесів, що відбуваються в робочому просторі печі, та неперервному взаємозв'язку між тепловими та електричними перетвореннями. Такий підхід дає можливість реалізувати опис у вигляді алгоритму, розрахункові блоки якого побудовані за рахунок використання методів: із теорії електричних кіл, опису об'ємного простору на базі циліндричних координат та аналізу процесів переміщення теплової енергії в матеріалах з різним агрегатним станом за рахунок теплопередачі.

Результати. Створена 3D картина температурного поля у ванні печі за перебігом технологічного процесу, що дає змогу в реальному часі визначити температурний стан елементарних об'ємів і моменти появи розплаву в них. Останнє дає можливість виділити зони печі, що потребують додаткового введення енергії, розрахувати об’єм і динаміку утворення готового розплаву та час його випуску. За рахунок отриманої інформації щодо фізичного стану шихти в будь-якому місці робочого простору печі стало можливим відстеження динаміки зміни рельєфу поверхні матеріалу й визначення місця засипання шихти в динаміці.

Наукова новизна. Отримана можливість визначення розподілу енергії у ванні руднотермічної печі в динаміці та розрахунку температурного поля в ній. Створена математична модель процесу виплавки феросплавів, в якій уперше враховано взаємозв'язок електричних і теплових процесів в об'ємі шихти за перебігом часу та є можливість визначення показників, що впливають на енергоефективність плавки.

Практична значимість. Використання запропонованої моделі дозволяє розрахувати кількість уведеної енергії до будь якого елементарного об'єму ванни руднотермічної печі за певний проміжок часу, вирішувати практичні задачі енергоефективності процесу.

Ключові слова: руднотермічна піч, електрична енергія, питомий електричний опір

\section{Определение распределения введенной энергии в объеме руднотермической печи}

\section{Ю. Г. Качан, В. Ю. Мищенко}

Запорожский национальный технический университет, г. Запорожье, Украина, e-mail: m.vlad.u@i.ua

Цель. Создание математической модели процесса ввода энергии в руднотермическую печь и ее распределения по объему с учетом как электрических, так и тепловых явлений, происходящих в ней, и представления ванны в виде совокупности элементарных составляющих. Последние, за счет электрического сопротивления, потребляют электроэнергию, которая превращается в тепловую, а затем перераспределяется в объеме путем теплопередачи. Это в дальнейшем даст возможность получить 3D картину изменения температурного поля рабочего пространства и решать практические задачи по повышению энергоэффективности как самого процесса получения ферросплавов, так и короткой электрической сети питания печи.

Методика. Создание математической модели базируется на реальной последовательности процессов, происходящих в рабочем пространстве печи, и непрерывной взаимосвязи между тепловы- 
ми и электрическими преобразованиями. Такой подход дает возможность реализовать описание в виде алгоритма, расчетные блоки которого построены за счет использования методов: из теории электрических цепей, описания объемного пространства на базе цилиндрических координат и анализа процессов перемещения тепловой энергии в материалах с различным агрегатным состоянием за счет теплопередачи.

Результаты. Создана 3D картина температурного поля в ванне печи по ходу технологического процесса, что позволяет в реальном времени определить температурное состояние элементарных объемов и моменты появления расплава в них. Последнее дает возможность выделить зоны печи, требующие дополнительного введения энергии, рассчитать объем и динамику образования готового расплава и время его выпуска. За счет полученной информации о физическом состоянии шихты в любом месте рабочего пространства печи стало возможным отслеживание динамики изменения рельефа поверхности материала и определение мест засыпки шихты в динамике.
Научная новизна. Получена возможность определения распределения энергии в ванне руднотермической печи в динамике и расчета температурного поля в ней. Создана математическая модель процесса выплавки ферросплавов, в которой впервые учтены взаимосвязь электрических и тепловых процессов в объеме шихты во времени и имеется возможность определения показателей, влияющих на энергоэффективность плавки.

Практическая значимость. Использование предложенной модели позволяет рассчитать количество введенной энергии в любой элементарный объем ванны руднотермической печи за определенный промежуток времени, решать практические задачи энергоэффективности процесса.

Ключевые слова: руднотермическая печь, электрическая энергия, удельное электрическое сопротивление

Рекомендовано до публікації докт. техн. наук Д. С.Яримбашем. Дата надходження рукопису 04.03.18. 